\title{
Education and Social Structure in a Restructuring Economy: Vietnam as Case Study
}

\author{
Le Ngoc Hung \\ Professor. Institute for Sociology, Ho Chi Minh National Political Academy \\ 135 Nguyen Phong Sac, Cau Giay, Hanoi, Vietnam \\ Hungxhh@gmail.com \\ Bui Thi Phuong \\ $\mathrm{PhD}$ student on Sociology, University of Social Sciences and Humanities, \\ 336 Nguyen Trai, Thanh Xuan, Ha Noi, Vietnam. \\ Phuongbui.sociology@gmail.com
}

\begin{abstract}
This paper focuses on the analysis of concepts of social stratification and justice and statistics of the rate of schooling children at the right age and related data to clarify some very important points like (1) the rate of secondary schooling children and university at the right age in Vietnam is slow and uneven. That is very unequal among different social groups, especially between the rich and poor group; (2) the rate of unemployment among the graduates of secondary schools; (3) although there is a danger of unemployment many Vietnamese people are eager to make rational investment in further education, that is for university education rather than stopping and this tendency provides the country with great potential for sustainable development. Those are reasons for answer question why it is important to open more opportunities for education, i.e. increase the rate of different grade schooling at the right age, from kindergarten to tertiary education in order to reduce social inequity in the education and develop high quality human resources; at the same time, it requires to renovate the contents of education and capacity development not only for applying for jobs but creating employment as well, start-up business and creativeness for sustainable development.
\end{abstract}

Keywords: Social structure, social differentiation, social stratification, social equality, social inequality, education.

\section{BACK GROUND}

Recently, there have been different scientific forums to attract a number of scholars, managers and leaders to discuss how to renovate education system in Vietnam. However, most of their positions just base on the current situation of the education system to talk qualitatively about issues of the education and others but they are limited in the frame of education system. They do not view other urgent issues of the education such as the issue of social stratification, social inequity in the education of Vietnam in the condition of building a market economy oriented to socialism, realizing the objective of prosperous people, powerful nation and just and civilized society in the context of globalization and integration into the world economy. This paper aims to study issues of social inequality in the education system of Vietnam basing on the analysis of the outcomes of the Vietnam Living Standard Survey (VLSS) on the demography and housing in Vietnam and the outcomes of the consensus on Vietnam's household livelihood. The fundamental position of the paper is the comprehensive renovation course of the education in Vietnam should center in solving issues of social inequity caused by social stratification in the education on the principle of social equity targeting to sustainable development of human and society.

\section{SOME RESEARCH CONCEPTS}

\subsection{Social Differentiation}

According to theoretical approach of social stratification ${ }^{1}$, social stratification represents a form of social differentiation, therefore it requires to study the concept of social differentiation ${ }^{2}$. Social

\footnotetext{
${ }^{1}$ Le Ngoc Hung. "The theoretical approach of social stratification by Niklas Luhmann of the system". Journal of Information of social sciences. No 4 (376). 2014. Pg. 3-10, 42; Le Ngoc Hung. "Theory of system by Niklas Luhmann of social stratification". Journal Human study. No 2. 2014.
}

${ }^{2}$ Le Ngoc Hung. Sociology of education. Publisher of National University, Hanoi. 2013. 
differentiation is a process of formation of different social groups about one or some certain social features and characteristics.

Social Differentiation is also called social difference emphasizing the process causing social differentiation among individuals, social groups. Social difference that can be quantified and therefore it may lead to social stratification while social difference that can be qualified can result in social classification. Both social stratification and differentiation may lead to the formulation of different social groups, conflicts and even opposition. As soon as the polarization results in opposite social groups is social polarization. For example, economically social differentiation creates rich and poor group, correspondently a group of students coming from rich households and a group of students coming from poor families; in education, social differentiation creates a group of people who have had opportunities to go to school and other groups that do not have opportunities for schooling.

The social polarization may create different social groups in occupation such as paddy growing farmers, vegetable growing farmers, poets, writers, social scientists, teachers, doctors, pharmacists, businessmen and hundreds of other occupation. In this case, social polarization results in diversity of social groups in occupation.

\subsection{Social Stratification}

Social stratification may create social classes, lays opposite in terms of economy such as classes of wealth and classes without wealth, poor and rich. In this case, social polarization results in class division, especially social stratification and even deeply social injustice.

Social stratification represents social polarization creating different social classes in the social structure.

The above definition emphasizes that Social Stratification is a form of the process of social polarization with a characteristic of creating social lays, social groups with higher and power positions different in terms of one or more basic features. Among these features the most important ones are an economical, powerful, social prestige and educational ${ }^{1}$. For example, social stratification creates a layer of "top" rich and powerful and layer of bottom poor, powerless and even without any wealth - low neck small throw'.

In education, the social stratification is in the form of inequity among social groups in terms of indicators of education like the chance of school, the number of school years, type of schools, the level of spending on education and others. Among these indicators the chance of going to school is the most essential as it is maybe the simplest to measure and evaluate the degree of social stratification and social inequity in the education ${ }^{2}$. For example, to understand the degree of social stratification in education between urban and rural areas it requires just to evaluate the rate of schooling at the right age of the urban area in the relation to the that in the rural area. Similarly, one can measure the level of social stratification in education among different ethnic groups basing on the analysis of the rate of schooling at the right age of every group. In this paper the social stratification in education can be understood as social polarization in terms of opportunities of schooling that is measured the rate of schooling at the right age of different social groups.

\subsection{Social Justice}

The assessment and recognition of social justice in education is essential to research the concept of social equity and other related concepts.

The concept of social justice that is used to note the access and solve in the right way, without any discrimination basic social relations among individuals, groups of people in a society. These are principle correlations such as the correlation between duty and interest, cost and benefit, contribution and bonus and others.

\footnotetext{
${ }^{1}$ In this paper "education" includes also training except specific case that will be specified.

${ }^{2}$ Social stratification in education differs from educational stratification namely in stratification in premises of university education. The Law of Education, Article 9, point 4 provides: the system of university education are classified in three types: a) research oriented education; b) Application oriented education and; c) Practice oriented education. See The law of Tertiary Education (2012) of Vietnam effective in Jan 1, 2013.
} 
The social justice is closely linked to the position of the society about justice, about what is and what is not accepted, what can be and what cannot be forgiven while judging and deciding one's action ${ }^{1}$.

Social equity in education directly relates to the allocation of education opportunities for all individuals and social groups and communities.

The concept of social equity is rather abstract and not easy to understand, but in practice, we often take into account of social equity in our actions. For example, we need to use the concept of social equity in examining the following suggestions: upper-secondary education graduates with the results under the average level are not allowed to take admission exams for tertiary education; every one are permitted to take admission exams for tertiary education not more than 3 times consecutively. Why these provisions? What happen if these provisions are implemented in practice? The answers relate to social equity, for example, a person who graduates a secondary school with every results can take an exam and passes it with scores satisfying the admission requirements of tertiary education. So, why they are not allowed to?

Social equity is concretized into conduct principles and institutionalized into legislations or unwritten rules. By law, social equity is not the goal itself but a mean and a mechanism to realize social equity.

\subsection{Social Equality}

The concept of social equity is about the recognition and establishing equal conditions, opportunities and benefits for the existing and development of individuals and social groups.

In the relation to people the social equity is the conduct and relation to others people just like to oneself. At first hearing, it sounds idealist and utopia but insight it is about a specific action, behavior among people in every perspective of the life economically, politically and culturally.

In theory, social inequity means inequality in basic aspects of social life of different individuals and groups of people. In reality, the notion of social inequality is used mainly to note unequal social correlation that may bring about more power and benefits for ones and less power and benefits for others.

The concept of discrimination is not simply an unequal treatment. Discrimination is unequal treatment when one must treat some one equally and equal treatment when one needs to treat someone unequally ${ }^{2}$. Discrimination in education may be reflected in different forms, such as a school provides a group of children from rich families with opportunity for schooling while it takes away education opportunity for children from poor families.

\subsection{Equity, Equality and Human Right}

The concept of social equity and equality relate to the concept of justice, interest and respect to natural rights of human. The insight indicates that "social equality" belongs to human right to be equal in terms of existence, freedom, happiness and benefits. The social equality is one of basic human right that no one can infringe and reject it. President Ho chi Minh declared about this right at the right beginning moment of the birth of Democratic Republic of Vietnam. He opened his Democracy Declaration in September 2, 1945 as follows:

"Everybody born has to have the right to be equal. The Creator gives him the right that no one can infringe. The right to live, freedom and the right to seek for happiness".

These immortal words were also in the Democracy Manifesto of the United States in 1776. Broadly, these words mean that all nations in the world are born to be equal, they all have the right of surviving, being happy and freedom.

The Declaration of the human right and civil right of the French revolution in 1791 also says: "human is born free and equal in the power and benefit and he must be always free and equal for benefits. These are the rights that no one can deny"3.

\footnotetext{
${ }^{1}$ Amartya Sen. "Democracy and social justice". In Farrukh Iqbal and Jong-II You. Democracy, market economy and development: from Asia's point of view. The World Bank. Publisher World. Hanoi. 2002. Pgs. 2949.

${ }^{2}$ Ansel M. Sharp, Charles A. Register, Paul W. Grimes. Economics in social issues. Publisher of Labor. Hanoi. 2005. Pg. 277.

${ }^{3}$ Ho Chi Minh: Cllection. Volume 4. Publisher of National Politics. Hanoi. 2000. Pg. 1.
} 


\subsection{Freedom and Duty}

An old point of view is that freedom must be attached to duty. Therefore, there is a position that freedom should be limited to avoid disorganized freedom and freedom with anarchy. This position may be stemmed from a wrong understanding about human rights and from a wrong assumption that duty is a condition for freedom: to be free one should have duty. A new point of view is that duty requires freedom and hence the freedom provides condition for individuals to act with social responsibilities. According to this point of view an individual is responsible for his or her decision whenever he or she has had the right for freedom, ability and conditions to make a decision on free choice and decision. The theory of development as freedom by Amartya Sen - an Indian scholar, the economist of 1998 Nobel Prize - can help us to understand better this concept while he wrote without freedom and real capacity to do some thing one cannot be responsible for doing that thing. But, if he has had freedom and ability to do some thing that will load his shoulder obligation to consider weather to do that thing so it contains individual duty ${ }^{1}$. Then Amartya Sen wrote that freedom is necessary and sufficient condition of the duty.

\subsection{Social Equality in Education}

The discrimination in ethnic minority groups, religion, beliefs, sex, family origin, social and economic status may cause social inequality in education. Therefore, The Law in Education (2005), article 10 provide rights, duties, social equity and equality in education as follows:

"Schooling is the right and duty of citizens.

All citizens regardless their ethnics, religion, beliefs, sex, family and social and economic condition are equal in education opportunities.

The State realizes social equality in education, providing conditions for education for all...”2.

The social equality in education can be understood as the equality for education opportunities, study opportunities and namely opportunities for schooling by social groups. For example, children of ethnic minority groups must have schooling opportunities as equal to those from Kinh people; children from poor households must go to schools at the right age as those from rich households.

Social equality in education does not mean all school students having equal study results or all of them graduate with the same results. Their results depend on different factors such as their capacities, the degrees of their efforts in study. In this regard, students are not identical because they are individuals, with different characteristics, unique abilities.

There have been several new positions in the world about the relationship between justice, equity and equality. A modern American philosopher, John Rawls, has laid down his point of view "equity for equal opportunities" or "equality of fair opportunity". According to this the allocation of main physical and non-physical resources of the society must be allocated equally and on the basis of equity. He wrote "all essential wealth of the society - freedom and opportunities, money and incomes and the basis of the selfesteem - must be equally allocated until an unequal allocation of any of those resources is because of the benefits of the unhappiest ones"3.

Education with its opportunities and conditions also belong to wealth and basic resources of the society. Therefore, there must realize the principle of social equity and be equally allocated among all people and social groups.

\subsection{The Importance of Social Equity in Education}

Social justice of education opportunities should be particularly interested in, namely the opportunity to go to school because this is the basic functional requirements of the society set for each member of modern society. The unjust behavior and the social inequality in education reduces the effectiveness and benefits that education can bring to the lives of people and society.

\footnotetext{
${ }^{1}$ Amartya Sen. Development as Freedom. Statistical Publisher. Hanoi. 2002. Pg. 346.

${ }^{2}$ The Education Law and by-laws to instruct the compliance. Publisher of Statistics. Hanoi. 2006. Pg. 11.

${ }^{3}$ Cited by Tran Thao Nguyen. Economic philosophy "The theory of justice” by Philosopher John Rawls. Publisher World. Hanoi. 2006. Pg. 176.
} 
Being stripped education opportunities will result in bad direct long and short time consequences for individuals. World educational specialists indicate that a child who has been stripped school opportunity will not only be disadvantageous at his childhood but he will also be disabled through out his life. It is because in most of today societies one who does not have opportunities to develop his basic abilities such as to read, write, calculate ... can be seen as disabled. In communities which have completed compulsory university education one who does not have opportunity to enter a university there may be dangerous for him to be disabled in the sense that he has not fully developed his working intellectual capacities.

For communities, social inequity and equality in education represents the reason of social disorder, conflicts, poverty, being left behind, underdevelopment, and in sustainability. A famous scholar once says a stupid nation is a poor one.

\section{The Present Situation of Inequity in Education}

The results of survey indicate that schooling opportunities have been opened but they are not equally allocated among different groups of schooling ages from primary to upper-secondary education and especially college and tertiary ones. The legal base of opening up right age for primary education opportunities is provided in the Law of Compulsory Primary Education that was enforced by the National Assembly of Vietnam in 1991 where it is clearly provided that the State implement policies of primary education compulsory for grades 1 to 5 for all Vietnamese children from 6 to 14 years old. Thank to the implementation of the law and policies of compulsory primary education after ten years, from 2000 Vietnam completed compulsory primary education, but with different levels from locality to locality.

By 2009, the results of consensus of population and housing in Vietnam indicate localities such as Lai Chau, Dien Bien, Ha Giang, Son La provinces the rates of children at the right age going to primary schools were 80-83\% while in other localities like Hai Duong, Nam Dinh, Thai Binh, Da Nang, Bac Ninh the rates were much higher, $98 \%$. The consensus of population and housing in 2009 in Vietnam indicates that Vietnam has achieved the target of gender equality in the rate of schooling at the right age by both girls and boys nationally. But, the rate of schooling at the right age has been decreasing from $96 \%$ to about $10 \%$ in tertiary degree ${ }^{1}$ (Table 1). This proves that the opportunities of entering universities are not numerous if one cannot want to say it is limited and may entails the danger of inequality among social groups. Polarization and inequity in educational grades and levels between urban and rural areas, among different ethnic minority groups and especially among groups of rich and poor households increase strongly from lower-education to university.

Examining only the rate of university students at the right age: it is $23.3 \%$ in urban area, 7 times higher than it is in rural area, (3\%); the rate of rich group is $26.3 \%, 87$ times higher than that of the poor group $(0.3 \%)$. That is why if university education is paid by the state budget, say a package of VND 437 billion, the students from 20\% of very rich household groups enjoy VND 263 billion, accounting for $60.2 \%$ of the total; and, the students from $20 \%$ of the poorest household group can enjoy VND 3 billion, accounting for $0.7 \%$; the rest of the package is for the students from $60 \%$ of above average, average, poor groups of households. Another calculation indicates a group of students from average, poor and very poor households can enjoy VND 68 billion and the students from very rich and rich groups of households can benefit VND 369 billion, that is, 60\% students from average, poor and very poor can benefit only $16 \%$ while $40 \%$ of students from rich and very rich households enjoy more than $84 \%$ of the state subsidies for public university education.

\footnotetext{
${ }^{1}$ Until now, The Ministry of Education and Training has not provided annual statistics of the situation of entrance schools at the right age of different grades, levels of education from kindergarten to tertiary education, as well as data of the number of students graduated. It provides just the information of the number of students. This causes difficulties in assessing the social stratification, social inequality in education sector in Vietnam. However, one can estimate, for example, every year there are more than 900 thousand students graduating from upper-secondary schools among them about one-third (33 percent) of them enter universities. Though one cannot know exactly how many percentage this the number of secondary graduates accounts for of the total number of young people of the same age graduate from secondary schools. But, it is clear that the rate of entrance universities is really low now in Vietnam that is not sufficient to make changes in the quality of tertiary education.
} 
Table1. The rate of children going to schools at the right age, by urban, rural, ethnic features and household groups in Vietnam, 2009

Unit: \%

\begin{tabular}{|c|c|c|c|c|c|}
\hline & Primary & Lower- secondary & Upper- secondary & College & University \\
\hline National & 95.5 & 82.6 & 56.7 & 6.7 & 9.6 \\
\hline Male & 95.5 & 81.4 & 53.1 & 6.0 & 9.1 \\
\hline Female & 95.4 & 83.9 & 60.6 & 7.4 & 10.1 \\
\hline Urban area & 97.2 & 88.8 & 68.4 & 12.9 & 23.3 \\
\hline Rural area & 94.9 & 80.6 & 52.8 & 3.7 & 3.0 \\
\hline \multicolumn{7}{|c|}{ Features of ethnic } & 61.8 & 7.7 & 11.1 \\
\hline Kinh & 97.0 & 86.7 & 55.5 & 3.0 & 3.2 \\
\hline Tay & 97.5 & 87.6 & 29.9 & 1.6 & 1.1 \\
\hline Thai & 92.7 & 73.3 & 41.4 & 1.3 & 1.7 \\
\hline Muong & 95.7 & 83.3 & 15.4 & 0.9 & 1.1 \\
\hline Khmer & 86.4 & 46.3 & 6.6 & 0.2 & 0.2 \\
\hline H'Mong & 72.6 & 34.1 & 23.2 & 0.3 & 0.3 \\
\hline \multicolumn{7}{|l|}{ Five twenty percent household groups by living levels } \\
\hline Poorest & 88.9 & 59.0 & 44.2 & 1.8 & 1.0 \\
\hline Poor & 95.3 & 78.7 & 56.1 & 7.8 & 5.5 \\
\hline Average & 97.0 & 86.7 & 64.6 & 8.6 & 10.6 \\
\hline Rich & 97.5 & 99.6 & 82.3 & 11.6 & 26.3 \\
\hline Richest & 98.3 & 94.9 & &
\end{tabular}

Source: Ministry of Planning and Investment - General Office of Statistics. Consensus of Demography and Housing in Vietnam, 2009: Education in Vietnam: Analysis of major indicators. Hanoi. 2011. Pg. 36

Until 2012, the results of VLSS of 2012 indicate the rate of students going to primary schools at the right age increased from $89.3 \%$ in 2006 to $92.4 \%$ in 2012, but there is still $7.8 \%$ of children do not go to schools at the right age (table 2). In 2010, all provinces and cities were recorded completion of compulsory lower-secondary schools with $81.3 \%$ of lower-secondary schooling at the right age. After two years, it increased slightly, to $81.4 \%$ in 2012 . The rate of children going to upper-secondary schools at the right age increased slowly, from $53.9 \%$ in 2006 to $59.4 \%$ in 2012 , and the rate of children at the right age going to colleges and universities was under $20 \%$. This means that by 2012 about $19 \%$ of children at the age did not go to lower-secondary schools and about $40 \%$ of children at the age did mot go to upper-secondary schools and $80 \%$ of them did not go to colleges and universities. There is no big inequality in the rates of children at the right age going to primary schools between urban and rural areas. But, the difference between the urban and rural areas increases at the age of lower-secondary education and it is more clearly seen at the age of upper-secondary education: in 2012, the rate of children going to upper-secondary schools at the right age was $70 \%$ in the urban area while it was a bit over 55\% in the rural area. The degree of equality in upper-secondary schooling opportunity decreased very slowly, from 16 points in 2006 down to 14.6 points in 2012.

Table2. The rate of children going to primary and secondary schools at the right age, by urban, rural area in Vietnam 2006-2012

Unit: \%

\begin{tabular}{|c|c|c|c|}
\hline \multicolumn{5}{|c|}{ Primary education } & Lower-secondary education & Upper-secondary education \\
\hline $\mathbf{2 0 0 6}$ & 89.3 & 78.8 & 53.9 \\
\hline $\mathbf{2 0 0 8}$ & 88.3 & 78.4 & 54.2 \\
\hline $\mathbf{2 0 1 0}$ & 91.9 & 81.3 & 58.2 \\
\hline $\mathbf{2 0 1 2}$ & 92.4 & 81.4 & 59.4 \\
\hline \multicolumn{5}{|c|}{ Urban area } \\
\hline $\mathbf{2 0 0 6}$ & 89.7 & 82.8 & 66.3 \\
\hline $\mathbf{2 0 0 8}$ & 89.2 & 82.6 & 66.4 \\
\hline $\mathbf{2 0 1 0}$ & 92.8 & 86.0 & 69.6 \\
\hline $\mathbf{2 0 1 2}$ & 92.6 & 85.0 & 70.2 \\
\hline \multicolumn{5}{|c|}{ Rural area } \\
\hline $\mathbf{2 0 0 6}$ & 89.1 & 77.7 & 50.3 \\
\hline percent & 88.1 & 77.1 & 50.6 \\
\hline $\mathbf{2 0 1 0}$ & 91.6 & 79.7 & 54.4 \\
\hline $\mathbf{2 0 1 2}$ & 92.4 & 80.1 & 55.6 \\
\hline
\end{tabular}

Source: The General Office of Statistics, Results of Vietnam Living Standard Survey, 2012. Hanoi, 2014. Pg.78. 
Educational inequality among ethnic groups: Education opportunities have been opened that is in increased rate of all grade schooling at the right age of different social groups during the Doi Moi era. However, the results of The consensus of population and housing 2009 indicate that the rate of college and university at the right age of Kinh people is 55 times (11.1\%) higher than that of H'Mong people $(0.2 \%)$; the rate of upper-schooling at the right age of Kinh people is $61.8 \%, 9$ times higher than that $(6.6 \%)$ of H' Mong people.

By 2012, the inequality in lower-schooling opportunities and especially upper-schooling become more obvious among ethnic groups of people. It is especially clear in the difference in the rate of secondary schooling of the minority group of people. Only three ethnic groups Kinh, Tay and Hoa have had $60 \%$ rate of right age schooling and all the rest groups have had under $50 \%$ and the lowest rate are of H'Mong, Dao and Kho'-me. The inequality in the rate of schooling at the right age decreased in 2009 to 2012 but it is still clear, for example, the rate of upper-schooling at the right age of Kinh people is $65 \%$, five times higher than that of H'mong people, $12.7 \%$ (Table 3).

Table3. The rate of children going to schools at the right age in Vietnam, by ethnic groups of household heads, 2012

Unit: \%

\begin{tabular}{|c|c|c|c|}
\hline & Primary education & Lower-secondary education & Upper-secondary education \\
\hline Kinh & 93.0 & 84.5 & 65.1 \\
\hline Tay & 95.3 & 87.1 & 61.3 \\
\hline Thai & 92.5 & 78.4 & 35.0 \\
\hline Hoa & 94.8 & 81.9 & 69.8 \\
\hline Kho' me & 88.1 & 55.1 & 22.8 \\
\hline Muong & 93.3 & 84.7 & 47.1 \\
\hline Nung & 91.6 & 78.0 & 41.4 \\
\hline H'mong & 84.4 & 46.0 & 13.7 \\
\hline Dao & 89.2 & 61.8 & 17.5 \\
\hline Others & 88.4 & 61.1 & 28.2 \\
\hline
\end{tabular}

Source: The General Office of Statistics, Results of Vietnam Living Standard Survey, 2012. Hanoi, 2014. Pg.77.

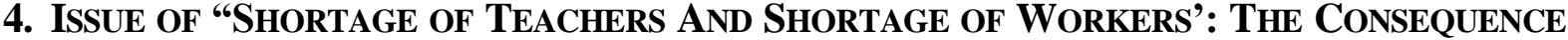 OF SOCIAL STRATIFICATION IN EDUCATION}

Causing by a narrow approach, bounded in educational frame and without an appropriate consideration of the requirements of the society, a number of authors try to criticize Vietnam for its expanding tertiary education that results in the situation of excess of teachers and shortage of workers". These critics are not based on the fact of degrees of the population of 15 years old and above of Vietnam. In 2009, the results of the consensus of Population and housing in Vietnam indicate the rate of the population of 15 years old and above of Vietnam having education of high level is $5.4 \%$, while that of Malaysia is $8.4 \%$, Philippines: $8.4 \%$, Korea: $23.4 \%$, Japan: $30 \%$, the United State: $36.2 \%$. The results of VLSS in 2012 of Vietnam show that the rate of the population of 15 years old and above of having education from "never going to school" to "completion of lowersecondary education" is about $70 \%$, having education from "primary vocational training" to "university and above" is $16.2 \%$, and the rest of $14 \%$ just "completion of upper-secondary school" (Table 4).

The number of people completing "universities" including "colleges" and above account for $7.4 \%$, the number of people having "technical skills and training" is $8.8 \%$ and the rest of $83.2 \%$ have not yet been trained. That is the ratio of human resources of Vietnam in 2012 is $7.4 \%$ "teachers", 8.8 workers who got skill training and $83.2 \%$ workers who have no training. From these numbers one can compute that 1 teacher has had 1.2 technician and 12 workers. Many do not know that this technical professional structure is the characteristic of poor labor force of a transitional economy to a market mechanism and under the process of industrialization and, modernization and integration in era of globalization with severe competition for goods and man power in today society. This means Vietnam is now in the shortage of both "teachers" and "workers" and excess of untrained labor. Other researchers often make comments, evaluations on education of Vietnam. It is necessary to say that the issue of "the shortage of teachers and workers is the result of very low rates of secondary enrolments and university admission of Vietnam in general and social stratification, particularly social inequality in education opportunities for these educational grades and levels in particular in Vietnam in recent time. 
Table4. Population structure of age of 15 years old and above by level of the highest degree, 2006 - 2012

\begin{tabular}{|c|c|c|c|c|c|c|c|c|c|c|c|c|}
\hline & All & $\begin{array}{c}\text { Never } \\
\text { going } \\
\text { to } \\
\text { school } \\
\quad s \\
\end{array}$ & $\begin{array}{l}\text { No } \\
\text { degre } \\
\text { es }\end{array}$ & $\begin{array}{c}\text { Finish } \\
\text { ing } \\
\text { prima } \\
\text { ry }\end{array}$ & $\begin{array}{c}\text { Completi } \\
\text { on of } \\
\text { lower- } \\
\text { secondar } \\
y\end{array}$ & \begin{tabular}{|c} 
Comple \\
tion of \\
upper- \\
seconda \\
ry \\
\end{tabular} & $\begin{array}{c}\text { Primary } \\
\text { vocation } \\
\text { al }\end{array}$ & $\begin{array}{l}\text { Secondary } \\
\text { vocational }\end{array}$ & $\begin{array}{l}\text { Vocationa } \\
1 \text { college }\end{array}$ & $\begin{array}{c}\text { Secondary } \\
\text { professional }\end{array}$ & $\begin{array}{l}\text { College, } \\
\text { university }\end{array}$ & $\begin{array}{c}\text { Over } \\
\text { univers } \\
\text { ity }\end{array}$ \\
\hline 2006 & 100 & 8.1 & 14.5 & 24.0 & 28.7 & 12.6 & - & - & - & 4.3 & 4.4 & 0.1 \\
\hline 2008 & 100 & 7.5 & 13.5 & 23.1 & 27.9 & 14.1 & 3.2 & 1.8 & 0.3 & 3.3 & 5.1 & 0.1 \\
\hline 2010 & 100 & 6.0 & 14.3 & 22.7 & 27.1 & 14.0 & 3.5 & 2.1 & 0.3 & 3.5 & 6.4 & 0.2 \\
\hline 2012 & 100 & 5.6 & 14.0 & 22.5 & 27.5 & 14.2 & 3.3 & 1.8 & 0.4 & 3.3 & 7.1 & 0.3 \\
\hline
\end{tabular}

Source: The General Office of Statistics, Results of Vietnam Living Standard Survey, 2012. Hanoi, 2014. Pg.69.

\section{ISSUE OF UNEMPLOYMENT AND SOCIAL STRATIFICATION IN EDUCATION}

Shall it be the more danger of unemployment as one gets to university education? The answer is No!

In 2014, the social opinion became more burning about 72 thousand university graduates became unemployed. The information of the number of unemployed university graduates became the burning theme of disputes then was based on the shortage of scientific data that made one confuse and result in decisions which can go opposite to the trend and requirements of high quality human resource development. To make the practical situation of unemployment of the university graduates it requires to do analysis if other information such as one need to know the total of university graduates and the number of students graduated and become unemployed a certain time and space frame. When it was asked about this information an official of education and training sector indicates on average every year about 400 thousand students graduated from universities. Then, if there are 72 thousand out of 400 thousand the graduates the rate of their unemployment is $18 \%$. And, if 72 thousand unemployed of two years then the rate is down to $9 \%$. From other side, it needs to study what degrees these 72 thousand graduates obtained so that one can make a judgment about the quality of education. It needs also to find reasons of unemployment in the ability of creating jobs by the economy for new graduates like when the state agencies and organizations try to reduce jobs, many firms are facing difficulties even closing down the danger of increased unemployment is not only for new graduates but also other working people. Here is still not about the characteristics and quality of labor and employment.

The results of a survey on labor and employment done by the General Statically Office (GSO) indicate that in 2012 there were 925.6 thousand unemployed people in Vietnam among them those who had upper-secondary education account for a big portion, $24.2 \%$ of the total unemployed, twice more than that $(10.1 \%)$ of the people who have had university and higher education (Table 5).

During 2010 - 2012, the rate of unemployed among those who have had under upper-secondary education decreased while that of those who have technical and professional education and training degrees increased, especially unemployment among those who have had college degree, from $2.7 \%$ up to $5.4 \%$. The rate of unemployment of university graduates increased $6.1 \%$ of the total number of 1.3 unemployed people up to $10.1 \%$ of the total 925.6 thousand, that is from 79.3 thousand to 93.5 thousand people in 2010 - 2012. This is a big number but it is equal to a half of the number of unemployed people who have only completed primary or secondary schools. This means that the risk of unemployment those who just completed secondary school may be twice bigger than for those who have had university and higher education. That is why, it hardly to infer the higher education one has had the bigger risk of being unemployed. And, then one may make a step-back solution: reducing universities to reduce unemployment.

A study about the shortage of labor in Vietnam indicates developing firms are difficult to recruit high technical quality and well-educated workers, meaning mainly the shortage of high-quality labor to increase labor productivity, quality and efficiency ${ }^{1}$.

Another noteworthy detail is that the rate of unemployment of people who have completed lowersecondary schools is $24.2 \%$ that is higher than that of those who just have had primary education and secondary education. Therefore, it can be understood that one who completed a primary school may seeks some how to work or to go for upper-secondary education for more job opportunity rather than

\footnotetext{
${ }^{1}$ Le Ngoc Hung. "The shortage of labor: A theoretical model and an issue of practical problem in Vietnam nowadays". Journal of Political Theory. Number 2/2014. Pg. 15-21.
} 
try to find a job after lower-secondary school because of bigger risk of unemployment and if he or she finds a job it may be a low-payment job.

Table5. Unemployed population structure by level of degrees, 2010 - 2012

\begin{tabular}{|c|c|c|c|c|c|c|c|c|}
\hline & \multicolumn{4}{|c|}{$\mathbf{2 0 1 0}$} & \multicolumn{4}{c|}{$\mathbf{2 0 1 2}$} \\
\hline Total & Male & Female & $\begin{array}{c}\text { \% of } \\
\text { female }\end{array}$ & Total & Male & Female & $\begin{array}{c}\text { \% of } \\
\text { female }\end{array}$ \\
\hline Never schooling & 100 & 100 & 100 & 56.1 & 100 & 100 & 100 & 54.6 \\
\hline $\begin{array}{c}\text { Not completed } \\
\text { primary school }\end{array}$ & 8.4 & 6.9 & 9.5 & 63.8 & 6.3 & 4.2 & 8.0 & 70.0 \\
\hline $\begin{array}{c}\text { Completed } \\
\text { primary school }\end{array}$ & 21.0 & 18.6 & 22.8 & 61.0 & 19.0 & 17.2 & 20.4 & 58.9 \\
\hline $\begin{array}{c}\text { Completed lower- } \\
\text { secondary school }\end{array}$ & 27.4 & 28.8 & 26.2 & 53.8 & 24.2 & 24.5 & 24.0 & 54.1 \\
\hline $\begin{array}{c}\text { Completed Upper- } \\
\text { secondary } \\
\text { education }\end{array}$ & 21.0 & 22.9 & 19.5 & 52.1 & 18.9 & 21.2 & 16.9 & 49.0 \\
\hline Vocational training & 4.4 & 7.2 & 2.2 & 27.6 & 6.8 & 11.2 & 3.2 & 25.9 \\
\hline $\begin{array}{c}\text { Secondary } \\
\text { professional }\end{array}$ & 5.3 & 4.1 & 6.3 & 66.6 & 6.8 & 5.6 & 7.7 & 62.4 \\
\hline College & 2.7 & 2.3 & 3.0 & 62.8 & 5.4 & 4.3 & 6.4 & 64.3 \\
\hline $\begin{array}{c}\text { University and } \\
\text { higher }\end{array}$ & 6.1 & 5.9 & 6.3 & 57.5 & 10.1 & 10.4 & 9.7 & 52.9 \\
\hline
\end{tabular}

Source: The General Office of Statistics, Results of consensus of labor and employment in Vietnam, 2010. Publisher of Statistics. Hanoi, 2011. Pg. 45. Results of consensus of labor and employment in Vietnam, 2012. Publisher of Statistics. Hanoi, 2013. Pg. 40.

\section{Social Stratification in Technical Proficiency and Income}

Many leaders, managers and some researchers criticize the fact "people rush to universities" without the knowledge of a simple reason that income level of university educated people is the highest and it is almost twice higher than that of those who have not gone through any professional and technical training. But, Vietnamese people, including very poor and least educated ones, know well the value and benefit of university education degree, and they are eager to spend money for the education, from kindergarten to university for their children ${ }^{1}$. Studies about how to choose occupation by students indicate that most (more than 90\%) of upper-secondary students plan to take exams for college and university after their completion of upper-secondary school ${ }^{2}$. There may find here great potential, internal energy for sustainable development of the country. Investments in study provide the rule of the development in a modern society. The Nobel Prize holders in economics like Gary Becker, Amartya Sen and famous sociologists like Collins, Coleman and Bourdieu all emphasize the importance of investments in education and training for the development of invisible capitals such as human, cultural and social capitals which are sharing increasing portions in of individuals', communities' and nations' assets. For example ${ }^{3}$, the share of these invisible capitals is $45 \%$ in the total capital per head of Vietnam in 2005, while this share of in OECD nations is $81 \%$.

Table 6 shows a monthly average income of way workers who have university and higher degrees is always 1.5 time higher than that of those who have lower education. What is noteworthy is that while average income of labor groups with other technical and professional qualifications was decreasing the income levels of labor of "secondary technical" and "university and higher education" groups increased in 2010 - 2012. It is clear that the expectation of higher income level and better working

\footnotetext{
${ }^{1}$ One can find evident for this statement in the notices about the mirrors of poor parents who have their children gained the first places at annual admission exams to universities.

${ }^{2}$ Bui Thi Thanh Ha - Ho Ngoc Tram. "Choice of occupation by upper-secondary school students at present”. Journal of Sociology. Number 1 (125). 2014. Pg. 20-33.

${ }^{3}$ The World Bank. Changes in the wealth structure of nations: Measuring sustainable development in a new decade. Washington. 2011. Pg. 186, 187. Le Ngoc Hung. Sociology of education. Publisher of National University, Hanoi. 2011..
} 
conditions for "university and higher" provides a sustainable motion promoting investments by households and individuals in university education regarding efforts made in grouping or dividing and orienting social opinions to vocational training after the completion of lower-secondary schools or after secondary education. It is necessary to recognize that the demand, motivation and efforts made in study for higher education, for admission in universities and higher represent necessary essential motive and internal force for the development of high quality man power to ensure the sustainable development of the country.

Table6. Monthly average income of wage employees and workers by levels of the highest technical qualification and skills, 2010 - 2012, Unit: thousand VND

\begin{tabular}{|c|c|c|c|c|}
\hline & \multicolumn{2}{|c|}{$\mathbf{2 0 1 0}$} & \multicolumn{2}{c|}{$\mathbf{2 0 1 2}$} \\
\hline All & 2519 & 100 & 3757 & 100 \\
\hline Not having technical training & 2108 & 83.7 & 3056 & 81.3 \\
\hline Vocational training & 2944 & 116.9 & 4272 & 113.7 \\
\hline Secondary professional training & 2472 & 98.1 & 3773 & 100.4 \\
\hline College & 2835 & 112.5 & 4146 & 110.4 \\
\hline University and higher & 4018 & 159.5 & 6077 & 161.8 \\
\hline
\end{tabular}

Source: The General Office of Statistics, Results of survey of labor and employment in Vietnam, 2010. Publisher of Statistics. Hanoi, 2011. Pg. 40. Results of survey of labor and employment in Vietnam, 2012. Publisher of Statistics. Hanoi, 2013. Pg. 34.

In short, education opportunities for all grades and levels of education have been opened and increased during the Doi Moi course from 1986 up to now. However, the situation of social stratification, social inequity in education are still high, especially in secondary and tertiary education, in the shortage of both teachers and workers. Therefore, it is necessary to promote the achievements of compulsory primary and lower-secondary education and move to compulsory pre-school, uppersecondary and university education. This becomes urgent to ensure social justice and social equality in education, development of high quality human resources and solve the problem of shortage of teachers and workers in an economy where there is a demand of increase its competitiveness basing on the application and renovation of technologies and sciences.

Profound and comprehensive renovation of education requires the renovation of leadership and management thought in education in the direction of the number, opening up more opportunities for schooling from pre-school to university education. Regarding the objective, education is not only for formulation of skills in "seeking for jobs" but to develop the ability of creating, self-employment creation, "business star-ups", in the learners ... as the contribution to socio-economic renovation and sustainable development of the country ${ }^{1}$. In case where there would not increase the quality of education and opening more education opportunities then priority should be given to opening up more opportunities for schooling, realizing social equity and social equality so that every body can go to school to achieve the objective of sustainable development of the country.

\section{REFERENCES}

Amartya Sen. Amartya Sen. "Democracy and social justice". In Farrukh Iqbal and Jong-II You. Democracy, market economy and development: from Asia's point of view. The World Bank. Publisher World. Hanoi. 2002. Pgs. 29-49.

Amartya Sen. Development is Freedom. Publisher of Statistics. Hanoi. 2002. Pg. 346.

Ansel M. Sharp, Charles A. Register, Paul W. Grimes. Economics on Social issues. Publisher of Labor. Hanoi. 2005. Pg. 277.

Ministry of Planning and Investment - General Statistical Office (GSO). The Consensus of Population and Housing in Vietnam 2009: Education in Vietnam: Analysis of major indicators. Hanoi. 2011. Pg. 36.

Socialist Republic of Vietnam. The Law of University Education (2012). Effective on 1/ January 2013.

\footnotetext{
${ }^{1}$ For details see The World Bank in the East- Asia - Pacific. Regional Report: Promote the Effectiveness of University Education - Skills and research for growth in the East-Asian Region. The World Bank. Washington, D.C. 2012.
} 
Ho Chi Minh: Collection. Volume 4. National Political publisher. Hanoi 2000 Pg. 1.

Le Ngoc Hung. "The theoretical approach of social stratification by Niklas Luhmann of the system". Journal of Information of social sciences. No 4 (376). 2014. Pg. 3-10, 42; Le Ngoc Hung. "Theory of system by Niklas Luhmann of social stratification". Journal Human study. No 2. 2014

Le Ngoc Hung. "The Theory of system by Niklas Luhmann about social stratification". Journal of Human Study. Number 2. 2014.

Le Ngoc Hung. "The shortage of labor: A theoretical model and an issue of practical problem in Vietnam nowadays". Journal of Political Theory. Number 2/2014. Pg. 15-21.

Le Ngoc Hung. Sociology of education. Publisher of National University, Hanoi. 2013.

The Law of Education and its by-laws. Statistics Publisher. Hanoi 2006. Pg 11.

The World Bank. Changes in the wealth structure of nations: Measuring sustainable development in a new decade. Washington. 2011. Pg. 186, 187.

Le Ngoc Hung. Sociology of education. Publisher of National University, Hanoi. 2011.

General Statistical Office (GSO). The Results of consensus in Labor and employment in 2010. Publisher of Statistics. Hanoi. 2011. Pg. 40; General Statistical Office. The Results of consensus in Labor and employment in 2010. Publisher of Statistics. Hanoi. 2011. Pg 34.

Tran Thao Nguyen. Economic philosophy "The theory of justice" by Philosopher John Rawls. Publisher World. Hanoi. 2006. Pg. 176.

\section{AUTHORS' BIOGRAPHY}

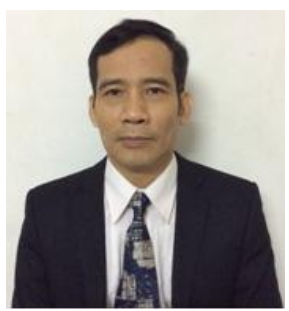

Prof. Dr. Le Ngoc Hung, Deputy Director of the Institute for Sociology, Ho Chi Minh National Academy of Politics, In-chief Editor of the Newsletter of Sociological Research (quarterly) at the Institute for Sociology, Ho Chi Minh National Academy of Politics.

He received his $\mathrm{PhD}$ on Sociology at the University of North Carolina at Chapel Hill, USA in 1996.

He is author and co-author of 110 articles in scientific journals including international journals and 25 books and monographs.

His in-depth research areas: social structure, social stratification, social differentiation, sociology of education, economic sociology, creative sociology, sociological theory, gender studies, social administration and management, social policy and rural development.

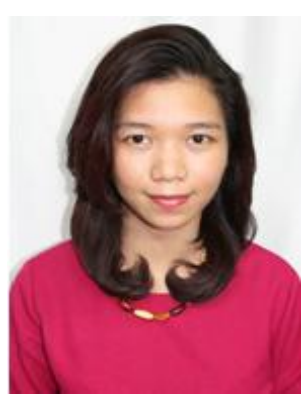

Bui Thi Phuong, Gender consultant, Hanoi Metropolitan Railway Management Board, PhD student on Sociology, University of Social Sciences and Humanities. Key researcher and manager of several international and national study projects.

She is author and co-author of many scientific articles and books.

In-depth research areas: social structure, social stratification, social differentiation, sociology of education, economic sociology, creative sociology, gender studies, social work, social administration, social policy and rural development. 